\title{
The use of stem cells in aesthetic dermatology and plastic surgery procedures. A compact review of experimental and clinical applications
}

\author{
Maciej Nowacki ${ }^{1}$, Tomasz Kloskowski², Katarzyna Pietkun ${ }^{3}$, Maciej Zegarski ${ }^{4}$, Marta Pokrywczyńska², \\ Samy L Habib ${ }^{5,6}$, Tomasz Drewa ${ }^{2,7}$, Barbara Zegarska ${ }^{3,4}$ \\ ${ }^{1}$ Chair and Department of Surgical Oncology, Ludwik Rydygier's Collegium Medicum in Bydgoszcz, Nicolaus Copernicus University \\ in Torun, Oncology Centre, Prof. Franciszek tukaszczyk Memorial Hospital, Bydgoszcz, Poland \\ ${ }^{2}$ Chair of Urology, Department of Regenerative Medicine, Cell and Tissue Bank, Ludwik Rydygier's Collegium Medicum in Bydgoszcz, \\ Nicolaus Copernicus University in Torun, Poland \\ ${ }^{3}$ Chair of Cosmetology and Aesthetic Dermatology, Ludwik Rydygier's Collegium Medicum in Bydgoszcz, Nicolaus Copernicus University \\ in Torun, Poland \\ ${ }^{4}$ Clinica Dermatoestetica, Inventionmed, Bydgoszcz, Poland \\ ${ }^{5}$ Department of Cellular and Structural Biology, University of Texas Health Science Center, San Antonio, TX, USA \\ ${ }^{6}$ Department of Geriatric, South Texas Veterans Health System, University of Texas Health Science Center, San Antonio, TX, USA \\ ${ }^{7}$ Department of Urology, Ludwik Rydygier's Collegium Medicum in Bydgoszcz, Nicolaus Copernicus University in Torun, Poland
}

Adv Dermatol Allergol 2017; XXXIV (6): 526-534

DOI: https://doi.org/10.5114/ada.2017.72456

\begin{abstract}
The aim of this paper was to collect currently available data related to the use of stem cells in aesthetic dermatology and plastic surgery based on a systemic review of experimental and clinical applications. We found that the use of stem cells is very promising but the current state of art is still not effective. This situation is connected with not fully known mechanisms of cell interactions, possible risks and side effects. We think that there is a big need to create and conduct different studies which could resolve problems of stem cells use for implementation into aesthetic dermatology and plastic surgery.
\end{abstract}

Key words: stem cells, aesthetic dermatology, plastic surgery.

\section{Introduction}

After many conducted experimental projects in the last decades of the $20^{\text {th }}$ century, stem cells (SC) were around twenty years ago announced as an innovative and promising remedy for many different diseases [1-4]. This hope related with specific properties of stem cells and their expected regenerative potential increases in direct proportion to the significant need in many medical specialties. Different scientific groups have started their projects on various preclinical and clinical levels focused only on the novel SC application methods and their use in alternative therapeutic protocols [5-8]. Thanks to many achievements resulting from basic, preclinical and translational experiments in 1992, the American scientist and writer Leland Kaiser established a new term "regenerative medicine" $[9,10]$. This term determines a new branch of medicine focused on effective SC implementation in patients with different chronic diseases [11-13]. The most known examples of SC introduction into treatment procedures are mostly connected with transplantation of hematopoietic stem cells (HSCT) and skin and adipose tissue grafting $[14,15]$. The data published by Eurostemcell show that SC are currently used in clinic in a very limited number of procedures and beside hematology or reconstructive surgery they are used mainly in skin grafts, which are prepared for severe burn trauma patients, or in ophthalmology in limbus corneal stem cell transplantation [16-18]. Beside the fact that hematopoietic stem cells were first transplanted to a patient with an irradiation injury 60 years ago and in Europe they are currently transplanted in more than 26000 patients yearly, there is still a serious problem with fulfillment

Address for correspondence: Prof. Barbara Zegarska MD, PhD, Chair of Cosmetology and Aesthetic Dermatology, Nicolaus Copernicus University, Ludwik Rydygier's Collegium Medicum, 15 Jagiellońska St, 85-067 Bydgoszcz, Poland, phone: +48 525853424 , fax: +48 525853425 , e-mail: baskazegarska@op.pl

Received: 9.09.2016, accepted: 4.01.2017. 
of the basic assumptions of regenerative medicine associated mainly with the solid organ regeneration and a simple SCs administration for each patient suffering from any chronic disease $[4,19,20]$. That is why, especially many last year's planned and conducted projects were considered with a potential supportive role and use of stem cells in such specialties like aesthetic dermatology and plastic surgery [21].

The aim of this work was to analyze and present in a compact review current achievements and knowledge about the use of stem cells in experimental and clinical aesthetic dermatology procedures.

\section{Potential stem cells sources and their implementation in current experimental and clinical aesthetic dermatology and plastic surgery}

Stem cells are currently intensively investigated for applications in a number of medical disorders including dermatological ones [22]. Mesenchymal stem cells (MSCs) seem to be an ideal source for tissue engineering application due to the lack of ethical concerns, high availability and increasing number of methods for isolation and expansion of such cell types. Each year on the market we can see new devices for MSCs expansion and culture, which allows to obtain a large number of cells, suitable for clinical application. Ability to differentiate into many cell types and lack of confirmed tumorigenic properties in comparison to embryonic stem cells or induced pluripotent stem cells, additionally argues for mesenchymal stem cells [23].

In dermatology and aesthetic surgery, a lot of disorders, currently incurable or with insufficient results after treatment, like psoriasis vulgaris, epidermolysis bullosa, systemic sclerosis, scleroderma, extensive burns, can be potentially the target of stem cell therapy (Table 1). Among MSCs, in dermatology the most popular ones include adipose derived stem cells (ADSCS) used alone after expansion in vitro or together with stromal vascular fraction (SVF) [24]. The first method is cost and time consuming but instead we obtain homogenous cells fraction with a fully defined phenotype. The use of SVF is cheaper and it could be applied during one surgical procedure. After their isolation and centrifugation, lipoaspirate cells could be directly applied to a patient. The disadvantage is a heterogeneous cell fraction; that is why it is not clear which cell type is responsible for regeneration processes [25]. It is possible to find on the market systems for automatic isolation of ADSCs, such terminology is misleading because cells isolated in such way will still be composed of heterogeneous or mixed population of cells found in adipose tissue [26]. The only way to obtain the appropriate number and homogenous adipose-derived stem cell population is its in vitro culture after isolation. Stromal vascular fraction is composed of fibroblasts, endothelial cells, smooth muscle cells, pericytes, immune cells and preadipocytes. The culture of SVF over time leads to elimination of most of these cell types leaving the population primarily composed of preadipocytes that display characteristics of multipotent stem cells [27].

Adipose derived stem cells were analyzed as a cell source for the full-thickness skin defect repair. Compared to control, cell therapy resulted in scar size reduction and provide better color quality and pliability of skin [28]. Stromal vascular fraction containing ADSCs was also used for treatment of face scars. This fraction was applied together with fat grafting which enhanced contour restoring compared to control in 1 year's followup [29]. Autologous fat grafting, containing ADSCs, was used for scar treatment on 20 patients in another study [30]. Application of this method leads to satisfactory aesthetic and functional results. This technique eliminated the pain and increased scar elasticity. Stem cells from lipoaspirates loaded into poly-3-hydroxybutyrate-co-hydroxyvalerat (PHBV) scaffold were examined on a mice model for full-thickness wound healing [31]. Twentyeight days after implantation wounds were closed and PHBV scaffold degraded completely. The PHBV scaffold together with ADSCs creates an optimal combination for wound healing. Scaffold induced scaring reduction while stem cells enhanced vascularization. Promising results were also observed when adipose-derived stem cells were applied with small intestine submucosa (SIS) scaffold [32]. In another study, ADSCs isolated from lipoaspirates was used alone, without scaffold, for treatment of skin defects on the facial area in 4 patients [33]. Stem cells in high density were applied on extracellular matrix consisting of squeezed fat directly to the defect location. Defects were repaired in all patients and used ADSCs showed excellent wound healing properties. Therapy using stem cells expanded in vitro is still relatively expensive, that is why authors of the mentioned publication concluded that such therapy is restricted to small defects. Our observations are similar, larger defects need using more stem cells. To obtain the proper cell number for cellular therapy, stem cells after isolation have to be expanded in vitro. In our unpublished data, we proved that ADSCs seeded at a density of 10 million cell per $\mathrm{cm}^{2}$ of scaffold gives a significant improvement in bladder regeneration with a reduction of scar formation compared to lower cell density and acellular scaffold. We have to remember that scaffold used for urinary tract regeneration is flat material (below $1 \mathrm{~mm}$ thickness), and defects in plastic surgery are much deeper. Expansion of the cell number in vitro needs using a large number of plastic culture flasks and culture media together with proper supplements which are still quite expensive. A similar experiment was conducted on 2 patients with necrosis and acute inflammatory reaction after facial filler injections [34]. In both cases satisfactory results were achieved. Another approach is differentiation of ADSCs obtained from 
Table 1. Selected studies registered on clinicaltrial.gov applies to safety of MSCs application in different dermatological disorders

\begin{tabular}{|c|c|c|c|c|}
\hline No. & Cell type & Condition & $\begin{array}{l}\text { Number of } \\
\text { patients }\end{array}$ & Number \\
\hline 1 & UC-MSCS & Psoriasis vulgaris & 30 & NCT02491658 \\
\hline 2 & ADSCS & $\begin{array}{l}\text { Lipodystrophies } \\
\text { Aesthetics procedure }\end{array}$ & 25 & NCT02034786 \\
\hline 3 & ADSCs & $\begin{array}{l}\text { Romberg's disease } \\
\text { Craniofacial microsomia } \\
\text { Lipodystrophy } \\
\text { Mixed connective tissue disease }\end{array}$ & 30 & NCT02494752 \\
\hline 4 & ADSC-SVF & $\begin{array}{l}\text { Safety of ADSC-SVF in: } \\
\text { Abnormally healing wounds } \\
\text { Scars } \\
\text { Doft tissue defects }\end{array}$ & 10 & NCT02590042 \\
\hline 5 & ADSC-SVF & $\begin{array}{l}\text { Safety of ADSC-SVF in: } \\
\text { Lipoatrophy } \\
\text { Aging } \\
\text { Wrinkles }\end{array}$ & 6 & NCT01828723 \\
\hline 6 & BM-MSCS & $\begin{array}{l}\text { Intrinsic aging of skin } \\
\text { Chronic effect of ultraviolet radiation on normal skin } \\
\text { (photo-aging) } \\
\text { Dermatologic disorders }\end{array}$ & 29 & NCT01771679 \\
\hline 7 & ADSCs & Micromastia & 20 & NCT02116933 \\
\hline 8 & ADSC-SVF & $\begin{array}{l}\text { Breast neoplasms } \\
\text { Skin abnormalities }\end{array}$ & 10 & NCT01801878 \\
\hline 9 & UC-MSCS & $\begin{array}{l}\text { Wounds } \\
\text { Diabetic foot ulcers } \\
\text { Burns }\end{array}$ & 30 & NCT02672280 \\
\hline 10 & PBSCT & Systemic scleroderma & 19 & NCT00278525 \\
\hline 11 & UC-MSCS & Burns & 20 & NCT01443689 \\
\hline 12 & BM-MSCS & $\begin{array}{l}\text { Scleroderma } \\
\text { Systemic sclerosis }\end{array}$ & 15 & NCT00040651 \\
\hline
\end{tabular}

PBSCT - peripheral blood stem cell transplantation, UC-MSCS - umbilical cord mesenchymal stem cells, ADSCS - adipose-derived stem cells, SVF-stromal vascular fraction, BM-MSCS - bone marrow mesenchymal stem cells.

lipoaspirates into adipocytes [35]. After in vitro differentiation, cells were injected subcutaneously to the scar in 31 patients. Twelve-week follow up resulted in scar size reduction. The proposed therapy was safe without any significant side effects. Hypertrophic scar reduction was also observed after application of ADSCs on a rabbit ear model [36]. In another study, a comparison of ADSCs with dermal fibroblasts was performed on a mice model. Cells were applied on a wound in collagen gel [37]. Both cells stimulated wound healing, however a greater effect was observed in the case of fibroblasts. The conditioned medium obtained from ADSCs culture combined with the fractional carbon dioxide laser resurfacing improved treatment of atrophic acne scars and skin rejuvenation. Combined therapy resulted in increased elasticity and hydration of the skin, increased collagen and elastin density and its proper arrangement. Overall satisfaction of the subjects was also noticed [38]. Wrinkles reduction using stem cell therapy was also considered. The skin of BALB/C nude rats was exposed to UV-B radiation to induce photoaged wrinkles after which ADSCs and fibroblast cells (control group) were applied. In both groups, wrinkles reduction was noted, a better effect was observed in the ADSCs group however both cell types induced collagen and metalloproteinase (MMP) production [39].

This cell type influence anti-aging properties by inhibition of melanin production after UV exposure resulting in skin whitening [40]. An anti-aging effect of stem cells from adipose tissue may result from glycation suppression, antioxidation and trophic effect, which in consequence leads to restoration of the functional capacity of the skin [41].

Bone marrow (BM) is another cell source frequently used for tissue engineering application in dermatology. The MSCs isolated from BM, similarly like ADSCs are well characterized and have excellent regenerative potential. The main factor that differs these two cell types is the 
source of cells. Isolation from bone marrow is a more invasive and harmful procedure for patients [42].

BM-MSCs isolated from BM aspiration after granulocyte colony-stimulating factor (G-CFS) stimulation were used for acne scars treatment. The study was performed on 14 patients, 6 months after treatment with a single dose of BM-MSCs, a significant improvement without any side-effects was observed [43]. Study utilizing the conditioned medium (CM) from bone-marrow MSCs was used for wrinkles treatment. An experiment performed on a rat model showed that CM from BM-MSCs increase pro-collagen synthesis in a dose-dependent manner inducing skin damage repair after UV action [44]. After intra-venous administration, BM-MSCs migrate to the wound site and stimulate the wound repair, which was confirmed on a mice model [45]. A combination of these cells with collagen sponges was applied for wound healing in mice. Obtained results showed that such connection is a promising way for soft tissue regeneration [46]. Autologous BM-MSCs in fibrin spray after approximately 2-week in vitro expansion was used for treatment of acute and chronic non-healing wounds in 10 patients [47]. In acute wounds, complete healing was observed 7-8 weeks after the procedure and within 16-20 weeks in patients with chronic wounds. BM-MSCs were also used for preventing contractions of skin grafts after transplantation in a patient with hypertrophic scars [48]. Stem cells were transplanted into the scar excision wound and then covered with decellularized dermal matrix and next with split-skin graft. After 2-year follow up, the proposed approach resulted in contraction reduction. Some studies suggest that all bone marrow cells have better regenerative potential in wound healing in comparison to more manipulated in vitro pure BM-MSCs [49].

Other cell sources like amniotic fluid stem cells (AFSCS), umbilical cord blood stem cells (UB-MSCs) or Warthon's jelly (WJ-MSCs) were also considered for application in dermatological disorders $[50,51]$. These cell types have greater proliferative and differentiation potential compared to ADSCs and BM-MSCs. A disadvantage is availability of cells for regenerative purposes. Umbilical cord blood allows to obtain a small number of cells, which is not sufficient for majority of clinical disorders, even after in vitro expansion [52]. The amniotic fluid is collected during planned amniocentesis, during which a small number of material can be obtained, and similarly like in case of UB-MSCs, generation of an appropriate cell number is difficult. Additionally, the amniotic fluid (AF) collection is associated with a risk of fetus damage [53].

Two million AFSCs together with amniotic membrane matrix were injected directly into the thoracotomy scar [54]. Substantial tissue remodeling and full relief of pain was observed about 12 weeks after therapy initiation, cells were delivered three times. Mesenchymal stem cells derived from the umbilical cord and WJ-MSCs were examined on a mice wound full-thickness defect model.
Advantages of wound healing and wound re-epithelialization after cell implantation were not observed in both cases compared to controls [55]. The paracrine effect of WJ-MSCs may be responsible for skin wound healing promotion. Experiments performed in vitro and in vivo on a mouse model indicated that this cell source enhanced expression of genes responsible for wound healing and positively regulates cell survival, proliferation and migration [56]. A combination of WJ-MSCs seeded on the decellularized amniotic membrane creates a great connection for skin injury treatment having better healing results with hair growth compared to the injection of MSCs alone [57].

\section{The current technical aspects of stem cells obtaining and their application methods}

Gimble et al. characterized in a precise way the most important factors related to the procedures created for most effective receiving of stem cells. Those authors suggest that SCS should be always obtained in a safe way using a minimally invasive procedure from the anatomical regions constituting biologically wealthy niches for a potentially large number of stem cells, which could be later simply used directly or could be prepared using Good Manufacturing Practice (GMP) guidelines for several different medical procedures [58]. The most promising types of stem cells which could meet these criteria include ADSC [21, 59]. This group of cells is a great hope for current aesthetic dermatology and plastic surgery mainly because of the well-known and described, and what is most important, very widely used fat grafting methods based on centrifuged and noncentrifuged fat $[60,61]$. The simple potentially translational process of fat transfer methodology and SCs separation with later cell cultivation has been presented in Figure 1. One of very interesting and still controversial technical aspects connected with novel SCs application methods in different medical specialties is the selection of place from which the SC should be derived $[62,63]$. As mentioned before, many authors suggest that especially for the aesthetic procedures, the best "first choice" select option is the use of transferred fat $[64,65]$. The most effective potential SC sources based on anatomical regions for fat transfer are presented in Figure 2.

\section{Possible positive effects, emerging clinical problems and side effects}

Aesthetic dermatology and plastic surgery are strongly connected with two medical and social terms: 1$)$ patient satisfaction and 2) possible side effects $[66,67]$. It could be also stated that both terms directly result from the specificity of both specializations where the patient finds himself mainly as a consumer and expects only fully satisfactory changes in appearance $[68,69]$. It should be also indicated that the topics associated with the pos- 

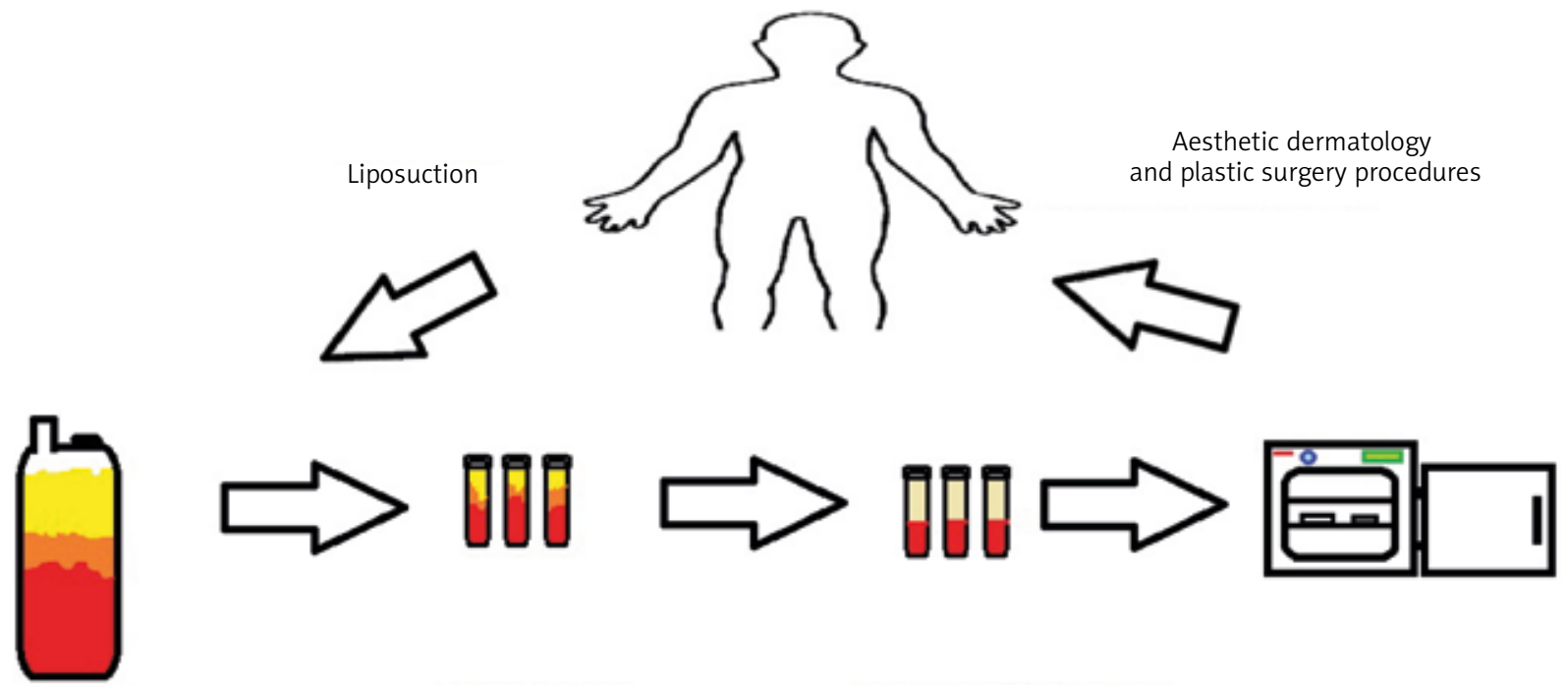

Lipoaspirate

Aspirate wash

Digestation with enzymes

Cell cultivation

Figure 1. A potentially effective and low cost translational process of fat transfer and SC separation for later cell cultivation
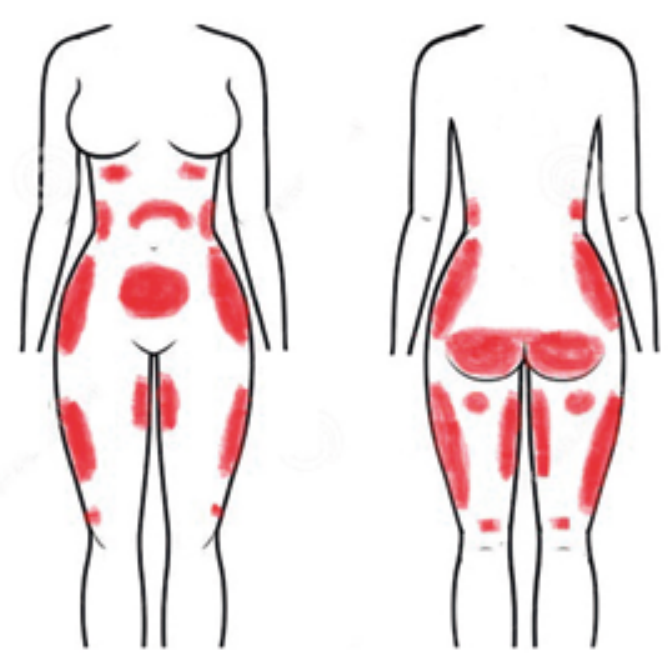

Figure 2. The most effective potential of SC sources based on currently top selected anatomical regions for fat transfer

sible side effects of any procedures used in aesthetic dermatology and plastic surgery should be always considered as first when planning the treatment strategy, and always during the various stages of the natural learning curve by dermatological and surgical beginners [70-72]. This rule applies also to the use of methods which are introduced as novel. Such innovative concepts include the topics of stem cell implementation. The full and precise evaluation and standard assessment of potential positive effects, emerging clinical problems and possible side effects in this scientific area is still problematic as it was shown in previous chapters due to the fact that there is still significant preponderance of basic and pre-clinical studies on expanded clinical trials [73]. This situation affects also the fact that currently only some projects have achieved the second phase of clinical trials or have obtained the acceptance and approval of the Federal Drug Administration (FDA), European Medicines Agency (EMA) and other representative supervision and legal agencies or institutes [74]. The most known representative examples include the project registered by Antria number \# NCT02526576 concerning to the use of SVC containing adipose derived stem cells in facial fat grafting. The general and compact assessment based on representative statistical analysis of the possible positive effects, emerging clinical problems and side effects is problematic due to the lack of thematic publications. As at the date of this publication, for example in spontaneous analysis of Pubmed records, the result for prefix ADSC with other selectively chosen thematic words showed: (ADSC + "selected word") $=47$ including words: aesthetic (23), dermatology (11), skin (47), rejuvenation (3), anti-aging (4), and cosmetic (8). As compared to the ADSC with words "plastic surgery" added, the number of records was 75 .

The currently listed clinical needs and suggested perspective ways of development are connected with improvement of the standard fat-transfer procedures for example by enhanced viability, better improvement of the survival of transplanted fat tissue or faster healing and regeneration of the targeted anatomical area $[75,76]$.

The potential positive effects of the use of stem cells in aesthetic dermatology and plastic surgery procedures are shown in Table 2 [77-83]. The main possible risk factors and side effects suggested in the literature are collected and presented in Table 3 [84-88]. 
Table 2. Selected potential positive effects of the use of stem cells in aesthetic dermatology and plastic surgery procedures

\begin{tabular}{|c|c|c|c|}
\hline $\begin{array}{l}\text { Type of suggested procedure } \\
\text { using stem cells }\end{array}$ & Type of suggested cells & $\begin{array}{l}\text { Potential positive effects/positive } \\
\text { influence/indications }\end{array}$ & References \\
\hline $\begin{array}{l}\text { Direct cell injection onto affected } \\
\text { region }\end{array}$ & $\begin{array}{l}\text { Adipose-derived stem } \\
\text { cells (ADSCs) }\end{array}$ & $\begin{array}{l}\text { Individual treatment to support the wound } \\
\text { healing process in complications after the } \\
\text { previous filler injection }\end{array}$ & Kim et al. [77] \\
\hline Cell-assisted lipotransfer (CAL) & $\begin{array}{l}\text { Adipose-derived SVF } \\
\text { (stromal vascular } \\
\text { fraction) cells }\end{array}$ & $\begin{array}{l}\text { Good aesthetic results in treatment of } \\
\text { breast augmentation and facial lipoatrophy }\end{array}$ & Mehrabani et al. [25] \\
\hline $\begin{array}{l}\text { Direct targeted supporting } \\
\text { implementation during platelet- } \\
\text { rich plasma injection }\end{array}$ & $\begin{array}{l}\text { Adipose-derived stem } \\
\text { cells (ADSCs) }\end{array}$ & Optimal scar reduction & Eun [78] \\
\hline $\begin{array}{l}\text { Stem cell-enriched tissue } \\
\text { injections (SET) }\end{array}$ & $\begin{array}{c}\text { Traditionally prepared } \\
\text { fat grafts with adipose- } \\
\text { derived regenerative cells } \\
\text { (ADRCs) }\end{array}$ & $\begin{array}{l}\text { Effective influence on fat-grafting } \\
\text { procedures performed especially in fibrosis } \\
\text { and post radiation cases }\end{array}$ & Tiryaki et al. [79] \\
\hline $\begin{array}{l}\text { Implementation of integrated } \\
\text { mesenchymal stem cells with } \\
\text { fibrin glue into the dressing of } \\
\text { burn wounds }\end{array}$ & $\begin{array}{l}\text { Bone marrow-derived } \\
\text { stem cells (BM-MSCs) }\end{array}$ & $\begin{array}{l}\text { Significantly faster healing of plastic } \\
\text { development of burn wounds }\end{array}$ & $\begin{array}{l}\text { Ghieh et al. [80] } \\
\text { Yang et al. [81] }\end{array}$ \\
\hline Stem cell intravenous injection & $\begin{array}{l}\text { Human umbilical cord- } \\
\text { derived mesenchymal } \\
\text { stem cells (UC-MSCs) }\end{array}$ & $\begin{array}{l}\text { Significantly increased neovascularization } \\
\text { and better burn wound healing }\end{array}$ & $\begin{array}{l}\text { Ghieh et al. [80] } \\
\text { Liu et al. [82] }\end{array}$ \\
\hline Direct subcutaneous injection & $\begin{array}{l}\text { Adipose-derived stem } \\
\text { cells (ADSCs) }\end{array}$ & Skin anti aging and regenerative effect & Zhang et al. [83] \\
\hline
\end{tabular}

\section{Conclusions}

Almost $80 \%$ of currently published reviews from the field of regenerative medicine in which the topic of the stem cell use in clinic is discussed are titled with a perverse question: how far we are currently with our knowledge about the potential use of SCs in different medical specialties and what we know about their effectiveness, indications for such procedures and their possible side effects [89]. That is why many authors title they work with short phrases like: stem cells hype or hope, stem cell myths and much more other statements [90]. This situation is related also to the papers concerning the implementation of SCs during aesthetic procedures where some authors refer to significance of this novel therapeutic option and directly demonstrate if SCs are now the fact or still fiction and futuristic concept [91]. There are also many papers in which the authors critically or very deeply but without hard and clear final statements, discuss the future of stem cell application and their use in clinic [92].

The natural search for new treatment possibilities together with a highly developing and large business market is very fast influenced by implementation of the topic "stem cells" in the classic and aesthetic dermatology and plastic surgery. For proper understanding of such intensive search for new and effective procedures, the following the fact is important - the invasive and noninvasive cosmetic procedures market is estimated at
Table 3. Main possible risk factors and side effects suggested in the literature related to the use of SC in medical procedures

\begin{tabular}{lc}
\hline Possible side effects and risks & References \\
\hline Rejection of stem cells & Herberts et al. [84] \\
\hline Neoplasm formation & Arnhold et al. [85] \\
\hline Undesired immune response & Herberts et al. [84] \\
\hline $\begin{array}{l}\text { Uncontrolled (non-planned) } \\
\text { differentiation }\end{array}$ & Fortin et al. [86] \\
\hline Unexpected cell contamination & Torsvik et al. [87] \\
\hline Unsatisfactory clinical effect & Thomsen et al. [88] \\
\hline
\end{tabular}

12.5 billion dollars in the US yearly with a great representative number of non-surgical procedures of 10,591,506 in 2014 [93]. The data published by the International Society of Aesthetic Plastic Surgery (ISAPS) in the International Survey on Aesthetic/Cosmetic Procedures performed in 2014 present the number of non-surgical procedures counted and registered for European countries like Germany or France at around 1 million procedures in both. The demand for such procedures is still growing, and the estimated increase in the number of such procedures oscillates at around $750 \%$ comparing each decade [94]. 
Such big need and still growing patient expectations like better final outcome or longer persistence of the aesthetic effect obtained, to some degree has influenced also the faster creation of new projects based on the translational and experimental studies oriented at the use of SCs. In this paper we have presented the potential stem cells sources and their implementation in current experimental and clinical aesthetic dermatology and plastic surgery applications. We have supported this material also with data related to the current technical aspects of stem cells obtaining and their application methods. We have discussed the possible positive effects, emerging clinical problems and side effects.

In comprehensively analyzed material we have found that there is still a lack of fully translational and advanced clinical studies in which the use of SCs could be successfully assessed. There are still no randomized or large cohort group data from the field of aesthetic dermatology and plastic surgery from which the hard arguments pro or against SC use in different aesthetic procedures could be formulated. But in the literature one can find a lot of basic and pre-clinical in vitro and in vivo studies with promising results. Those projects are mainly related to the SC obtained due to the fat liposuction procedure with flagship application ideas of ADSC.

In our opinion, the use of stem cells in aesthetic dermatology and plastic surgery procedures is very promising but currently still not possible and according to the current state of art, not effective. This situation is related to still not fully known mechanisms of cell interactions and possible risks and side effects. We think that there is still a big need to create and conduct different basic and pre-clinical studies which could resolve current problems of SC use and can significantly accelerate their implementation into aesthetic dermatology and plastic surgery.

\section{Conflict of interest}

The authors declare no conflict of interest.

\section{References}

1. Nowacki M, Kloskowski T, Pokrywczyńska M, et al. Is regenerative medicine a new hope for kidney replacement? J Artif Organs 2014; 17: 123-34.

2. Mead B, Berry M, Logan A, et al. Stem cell treatment of degenerative eye disease. Stem Cell Res 2015; 14: 243-57.

3. Bitar KN, Raghavan S. Stem cell therapy for GI neuromuscular disorders. Curr Gastroenterol Rep 2014; 16: 419.

4. Copelan EA. Hematopoietic stem-cell transplantation. N Engl J Med 2006; 354: 1813-26.

5. Nowacki M, Jundziłł A, Nazarewski Ł, et al. Blood vessel matrix seeded with cells: a better alternative for abdominal wall reconstruction - a long-term study. Biomed Res Int 2015; 2015: 890613.

6. Kim N, Cho SG. Clinical applications of mesenchymal stem cells. Korean J Intern Med 2013; 28: 387-402.
7. Jiang J, Miao Y, Xiao S, et al. DAPT in the control of human hair follicle stem cell proliferation and differentiation. Postep Dermatol Alergol 2014; 31: 201-6.

8. Dalberto TP, Nardi NB, Camassola M. Mesenchymal stem cells as a platform for gene therapy protocols. Sci Prog 2010; 93: 129-40.

9. Schmitt A, van Griensven M, Imhoff AB, et al. Application of stem cells in orthopedics. Stem Cells Int 2012; 2012: 394962.

10. Madariaga ML, Ott HC. Bioengineering kidneys for transplantation. Semin Nephrol 2014; 34: 384-93.

11. Tartarini D, Mele E. Adult stem cell therapies for wound healing: biomaterials and computational models. Front Bioeng Biotechnol 2016; 3: 206.

12. Wang L, Zhang Y, Li H, et al. Clinical observation of employment of umbilical cord derived mesenchymal stem cell for juvenile idiopathic arthritis therapy. Stem Cells Int 2016; 2016: 9165267.

13. Nowacki M, Nazarewski Ł, Pokrywczyńska M, et al. Long-term influence of bone marrow-derived mesenchymal stem cells on liver ischemia-reperfusion injury in a rat model. Ann Transplant 2015; 20: 132-40.

14. Marks R, Finke J. The impact of stem cell therapy in hematology and oncology. Internist (Berl) 2006; 47: 467-8.

15. Koźlik M, Wójcicki P. The use of stem cells in plastic and reconstructive surgery. Adv Clin Exp Med 2014; 23: 1011-7.

16. van Servellen A, Oba I. Stem Cell Research, Trends and Perspectives on the Evolving International Landscape. Elsevier 2014.

17. Mitra S. Combined autologous and allograft limbal cell transplantation with penetrating keratoplasty in a case of chemical corneal burn patient. Oman J Ophthalmol 2009; 2: 126-9.

18. Huang L, Burd A. An update review of stem cell applications in burns and wound care. Indian J Plast Surg 2012; 45: 229-36.

19. Liu Y, Yang R, He Z, et al. Generation of functional organs from stem cells. Cell Regen (Lond) 2013; 2: 1.

20. Gennero L, Mortimer P, Sperber K, et al. Stem cells: an alternative to organ transplantation in chronic, degenerative and infectious diseases? New Microbiol 2006; 29: 151-67.

21. Nowacki M, Pietkun K, Pokrywczyńska M, et al. Filling effects, persistence, and safety of dermal fillers formulated with stem cells in an animal model. Aesthet Surg J 2014; 34: 1261-9.

22. Otero-Vińas M, Falanga V. Mesenchymal stem cells in chronic wounds: the spectrum from basic to advanced therapy. Adv Wound Care (New Rochelle) 2016; 5: 149-63.

23. Satija NK, Singh VK, Verma YK, et al. Mesenchymal stem cellbased therapy: a new paradigm in regenerative medicine. J Cell Mol Med 2009; 13: 4385-402.

24. Ong WK, Sugii S. Adipose-derived stem cells: fatty potentials for therapy. Int J Biochem Cell Biol 2013; 45: 1083-6.

25. Mehrabani D, Mehrabani G, Zare S, et al. Adipose-derived stem cells (ADSC) and aesthetic surgery: a mini review. World J Plast Surg 2013; 2: 65-70.

26. Di Giuseppe A, Wolf D. Breast augmentation with stem cellenhanced fat transfer: comparison between enhanced and unenhanced fat grafting. In: Stem Cells in Aesthetic Procedures: Art, Science, and Clinical Techniques. Shiffman MA, Di Giuseppe A, Bassetto F (eds). Springer. Heidelberg, New York,Dordrecht, London 2014; 563-72.

27. Wankhade UD, Shen M, Kolhe R, Fulzele S. Advances in adipose-derived stem cells isolation, characterization, and application in regenerative tissue engineering. Stem Cells Int 2016; 2016: 3206807. 
28. Yun IS, Jeon YR, Lee WJ, et al. Effect of human adipose derived stem cells on scar formation and remodeling in a pig model: a pilot study. Dermatol Surg 2012; 38: 1678-88.

29. Gentile P, De Angelis B, Pasin M, et al. Adipose-derived stromal vascular fraction cells and platelet-rich plasma: basic and clinical evaluation for cell-based therapies in patients with scars on the face. J Craniofac Surg 2014; 25: 267-72.

30. Klinger M, Caviggioli F, Klinger FM, et al. Autologous fat graft in scar treatment. J Craniofac Surg 2013; 24: 1610-5.

31. Zonari A, Martins TM, Paula AC, et al. Polyhydroxybutyrateco-hydroxyvalerate structures loaded with adipose stem cells promote skin healing with reduced scarring. Acta Biomater 2015; 17: 170-81.

32. Lam MT, Nauta A, Meyer NP, et al. Effective delivery of stem cells using an extracellular matrix patch results in increased cell survival and proliferation and reduced scarring in skin wound healing. Tissue Eng Part A 2013; 19: 738-47.

33. Jo DI, Yang HJ, Kim SH, et al. Coverage of skin defects without skin grafts using adipose-derived stem cells. Aesthetic Plast Surg 2013; 37: 1041-51.

34. Sung HM, Suh IS, Lee HB, et al. Case reports of adiposederived stem cell therapy for nasal skin necrosis after filler injection. Arch Plast Surg 2012; 39: 51-4.

35. Kim M, Kim I, Lee SK, et al. Clinical trial of autologous differentiated adipocytes from stem cells derived from human adipose tissue. Dermatol Surg 2011; 37: 750-9.

36. Zhang Q, Liu LN, Yong Q, et al. Intralesional injection of adipose-derived stem cells reduces hypertrophic scarring in a rabbit ear model. Stem Cell Res Ther 2015; 6: 145.

37. Lee $\mathrm{SH}$, Lee $\mathrm{JH}$, Cho $\mathrm{KH}$. Effects of human adipose-derived stem cells on cutaneous wound healing in nude mice. Ann Dermatol 2011; 23: 150-5.

38. Zhou BR, Zhang T, Jameel AA, et al. The efficacy of conditioned media of adipose-derived stem cells combined with ablative carbon dioxide fractional resurfacing for atrophic acne scars and skin rejuvenation. J Cosmet Laser Ther 2016; 18: $138-48$.

39. Jeong JH, Fan Y, You GY, et al. Improvement of photoaged skin wrinkles with cultured human fibroblasts and adiposederived stem cells: a comparative study. J Plast Reconstr Aesthet Surg 2015; 68: 372-81.

40. Chang $\mathrm{H}$, Park JH, Min KH, et al. Whitening effects of ad ipose-derived stem cells: a preliminary in vivo study. Aes thetic Plast Surg 2014; 38: 230-3.

41. Zhang S, Dong Z, Peng Z, et al. Anti-aging effect of adiposederived stem cells in a mouse model of skin aging induced by D-galactose. PLoS One 2014; 9: e97573.

42. Strioga M, Viswanathan S, Darinskas A, et al. Same or not the same? Comparison of adipose tissue-derived versus bone marrow-derived mesenchymal stem and stromal cells. Stem Cells Dev 2012; 21: 2724-52.

43. Ibrahim ZA, Eltatawy RA, Ghaly NR, et al. Autologus bone marrow stem cells in atrophic acne scars: a pilot study. J Dermatolog Treat 2015; 26: 260-5.

44. Kwon TR, Oh CT, Choi EJ, et al. Conditioned medium from human bone marrow-derived mesenchymal stem cells (MSC-CdM) promotes skin moisturization and effacement of wrinkles in UVB-irradiated SKH-1 hairless mice. Photodermatol Photoimmunol Photomed 201; 32: 120-8.

45. Sasaki M, Abe R, Fujita Y, et al. Mesenchymal stem cells are recruited into wounded skin and contribute to wound repair by transdifferentiation into multiple skin cell type. J Immunol 2008; 180: 2581-7.
46. Markowicz M, Koellensperger E, Neuss S, et al. Human bone marrow mesenchymal stem cells seeded on modified collagen improved dermal regeneration in vivo. Cell Transplant 2006; 15: 723-32.

47. Falanga V, Iwamoto S, Chartier M, et al. Autologous bone marrow-derived cultured mesenchymal stem cells delivered in a fibrin spray accelerate healing in murine and human cutaneous wounds. Tissue Eng 2007; 13: 1299-312.

48. Xu Y, Huang S, Fu X. Autologous transplantation of bone marrow-derived mesenchymal stem cells: a promising therapeutic strategy for prevention of skin-graft contraction. Clin Exp Dermatol 2012; 37: 497-500.

49. Rodriguez-Menocal L, Shareef S, Salgado M, et al. Role of whole bone marrow, whole bone marrow cultured cells, and mesenchymal stem cells in chronic wound healing. Stem Cell Res Ther 2015; 6: 24.

50. Kluth SM, Radke TF, Kogler G. Potential application of cord blood-derived stromal cells in cellular therapy and regenerative medicine. J Blood Transfus 2012; 2012: 365182.

51. Kalaszczynska I, Ferdyn K. Wharton's jelly derived mesenchymal stem cells: future of regenerative medicine? Recent findings and clinical significance. Biomed Res Int 2015; 2015: 430847.

52. Harris DT. Umbilical cord tissue mesenchymal stem cells: characterization and clinical applications. Curr Stem Cell Res Ther 2013; 8: 394-9.

53. Dziadosz M, Basch RS, Young BK. Human amniotic fluid: a source of stem cells for possible therapeutic use. Am J Obstet Gynecol 2016; 214: 321-7.

54. Hemphill C, Stavoe K, Khalpey Z. First in man: amniotic stem cell injection promotes scar remodeling and healing processes in late-stage fibrosis. Int J Cardiol 2014; 174: 442-3.

55. Doi H, Kitajima Y, Luo L, et al. Potency of umbilical cord blood-and Wharton's jelly-derived mesenchymal stem cells for scarless wound healing. Sci Rep 2016; 6: 18844.

56. Arno Al, Amini-Nik S, Blit PH, et al. Human Wharton's jelly mesenchymal stem cells promote skin wound healing through paracrine signaling. Stem Cell Res Ther 2014; 5: 28.

57. Sabapathy V, Sundaram B, VMS, et al. Human Wharton's Jelly mesenchymal stem cells plasticity augments scar-free skin wound healing with hair growth. PLoS One 2014; 9: e93726.

58. Gimble JM, Katz AJ, Bunnell BA. Adipose-derived stem cells for regenerative medicine. Circ Res 2007; 100: 1249-60.

59. Koellensperger E, Bollinger N, Dexheimer V, et al. Choosing the right type of serum for different applications of human adipose tissue-derived stem cells: influence on proliferation and differentiation abilities. Cytotherapy 2014; 16: 789-99.

60. Kristensen RN, Gunnarsson GL, Børsen-Koch M, et al. Fast and simple fat grafting of the breast. Gland Surg 2015; 4: 572-6.

61. Ibatici A, Caviggioli F, Valeriano V, et al. Comparison of cell number, viability, phenotypic profile, clonogenic, and proliferative potential of adipose-derived stem cell populations between centrifuged and noncentrifuged fat. Aesthetic Plast Surg 2014; 38: 985-93.

62. Vadalà G, Russo F, Ambrosio L, et al. Stem cells sources for intervertebral disc regeneration. World J Stem Cells 2016; 8: 185-201.

63. Hyun I. The bioethics of stem cell research and therapy. J Clin Invest 2010; 120: 71-5.

64. Schendel SA. Enriched autologous facial fat grafts in aesthetic surgery: 3D volumetric results. Aesthet Surg J 2015; 35: $913-9$. 
65. Mazzola RF, Mazzola IC. History of fat grafting: from ram fat to stem cells. Clin Plast Surg 2015; 42: 147-53.

66. Rivers JK, Bertucci V, McGillivray W, et al. Subject satisfaction with onabotulinumtoxin A treatment of glabellar and lateral canthal lines using a new patient-reported outcome measure. Dermatol Surg 2015; 41: 950-9.

67. Kreyden OP, Rzany B, Becker-Wegerich P, et al. The satisfied patient in aesthetic dermatology. Consensus work on patient satisfaction in botulinum toxin A treatment. Hautarzt 2015; 66: 131-6.

68. Prakash B. Patient satisfaction. J Cutan Aesthet Surg 2010; 3: 151-5.

69. Rubin MG, Cox SE, Kaminer MS, et al. Correcting age-related changes in the face by use of injectable fillers and neurotoxins. Semin Cutan Med Surg 2014; 33: S81-4.

70. Lardi AM, Ho-Asjoe M, Mohanna PN, et al. Immediate breast reconstruction with acellular dermal matrix: factors affecting outcome. J Plast Reconstr Aesthet Surg 2014; 67: 1098105.

71. Demir A, Kucuker I, Keles MK, Demirtas Y. The effect of learning curve on flap selection, re-exploration, and salvage rates in free flaps: a retrospective analysis of 155 cases. Microsurgery 2013; 33: 519-26.

72. Cather JC, Cather JC, Menter A. Update on botulinum toxin for facial aesthetics. Dermatol Clin 2002; 20: 749-61.

73. Gimble JM, Guilak F, Bunnell BA. Clinical and preclinical translation of cell-based therapies using adipose tissuederived cells. Stem Cell Res Ther 2010; 1: 19.

74. Tremolada C, Beltrami G, Magri A, et al. Adipose mesenchymal stem cells and "regenerative adipose tissue graft" (Lipogems $^{\mathrm{tm}}$ ) for musculoskeletal regeneration. Eur J Musculoskeletal Dis 2014; 3: 57-67.

75. Bae YC, Song JS, Bae SH, et al. Effects of human adiposederived stem cells and stromal vascular fraction on cryopreserved fat transfer. Dermatol Surg 2015; 41: 605-14.

76. Ceylan HH, Bilsel K, Buyukpinarbasili N, et al. Can chondral healing be improved following microfracture? The effect of adipocyte tissue derived stem cell therapy. Knee 2016; 23: 442-9.

77. Kim JH, Ahn DK, Jeong HS, et al. Treatment algorithm of complications after filler injection: based on wound healing process. J Korean Med Sci 2014; 29: S176-82.

78. Eun Sc. Stem cell and research in plastic surgery. J Korean Med Sci 2014; 29: S167-9.

79. Tiryaki T, Findikli N, Tiryaki D. Staged stem cell-enriched tissue (SET) injections for soft tissue augmentation in hostile recipient areas: a preliminary report. Aesthetic Plast Surg 2011; 35: 965-71.

80. Ghieh F, Jurjus R, Ibrahim A, et al. The use of stem cells in burn wound healing: a review. Biomed Res Int 2015; 2015: 684084.

81. Yang Y, Zhang W, Li Y, et al. Scalded skin of rat treated by using fibrin glue combined with allogeneic bone marrow mesenchymal stem cells. Ann Dermatol 2014; 26: 289-95.

82. Liu L, Yu Y, Hou Y, et al. Human umbilical cord mesenchymal stem cells transplantation promotes cutaneous wound healing of severe burned rats. PLoS One 2014; 9: e88348.

83. Zhang S, Dong Z, Peng Z, et al. Anti-aging effect of adiposederived stem cells in a mouse model of skin aging induced by D-galactose. PLoS One 2014; 9: e97573.

84. Herberts CA, Kwa MS, Hermsen HP. Risk factors in the development of stem cell therapy. J Transl Med 2011; 9: 29.

85. Arnhold S, Klein H, Semkova I, et al. Neurally selected embryonic stem cells induce tumor formation after long-term survival following engraftment into the subretinal space. Invest Ophthalmol Vis Sci 2004; 45: 4251-5.

86. Fortin JM, Azari H, Zheng T, et al. Transplantation of defined populations of differentiated human neural stem cell progeny. Sci Rep 2016; 6: 23579.

87. Torsvik A, Røsland GV, Svendsen A, et al. Spontaneous malignant transformation of human mesenchymal stem cells reflects cross-contamination: putting the research field on track - letter. Cancer Res 2010; 70: 6393-6.

88. Thomsen GM, Gowing G, Svendsen S, et al. The past, present and future of stem cell clinical trials for ALS. Exp Neurol 2014; 262: 127-37.

89. Li Q, Zhang C, Fu X. Will stem cells bring hope to pathological skin scar treatment? Cytotherapy 2016: 18: 943-56.

90. Nadig RR. Stem cell therapy - hype or hope? A review. J Conserv Dent 2009; 12: 131-8.

91. McArdle A, Senarath-Yapa K, Walmsley GG, et al. The role of stem cells in aesthetic surgery: fact or fiction? Plast Reconstr Surg 2014; 134: 193-200.

92. Lambrou GI, Remboutsika E. Proliferation versus regeneration: the good, the bad and the ugly. Front Physiol 2014; 5: 10.

93. Goh C. The need for evidence-based aesthetic dermatology practice. J Cutan Aesthet Surg 2009; 2: 65-71.

94. Momeni A, Kim RY, Wan DC, et al. Aesthetic surgery training during residency in the united states: a comparison of the integrated, combined, and independent training models. Plast Surg Int 2014; 2014: 281923. 